\title{
CLAUDE LORRAIN: AN OLD MAN ON THE SEA SHORE
}

\begin{abstract}
Claude Lorrain was one of the first painters in the art history to break away from literary (religious, mythological) themes and to veer in the direction of more open interpretations of meaning. Works by Claude Lorrain that have positively identifiable themes are scenes of a narrative nature, yet the titles that were applied to such paintings - for instance Landscape with Acis and Galatea, Seaport with Ulysses Returning Chryseis to Her Father - would have been inconceivable to members of earlier generations. In the paintings of Claude, the viewer could celebrate not only the embodiment of beauty but also the art of beauty. Instead of being treated as a parable, subject to constant reinterpretation in accordance with the concept of the idea, the image could now be seen simply as a visualisation of the ideal of the individual. It is the landscape that takes precedence over the events themselves. Nature is not subjugated to expressing or suppressing human passions; nature is never anything but beautiful and indifferent, a backdrop to human action. In my study, I examine in detail a little known 1667 painting by Claude, which is in a private collection and the iconographic status of which is uncertain.

Keywords: landscape, seaport scene, literary themes in painting, Claude Lorrain: An Old Man (or Prophet Ezekiel, or Paul the Apostle, or Demosthenes) on the Sea Shore, Nicolas Poussin
\end{abstract}

We find ourselves in a fortunate situation today, in that the above title - or to be more precise: Sea Shore with an Old Man - is the only one that we can apply with absolute certainty to the painting by Claude Lorrain (1600?-1682) that I intend to discuss below (Fig. 1). No more specific identification of the subject of the painting has been handed down to us. In the eighteenth and nineteenth centuries, it was believed that the tall, elderly gentleman walking with dignity along the shore, with his right hand clutched to his breast and a scroll of parchment in his left, was Demosthenes, the Greek orator and politician. ${ }^{1}$ A sketch with a similar composition to the one in the painting served as the basis for suggestions that the figure could be the Prophet Jonah, but as the whale in the sketch, fading into the distant ocean, appears neither

\footnotetext{
* Sándor Radnóti, professor emeritus, Institute for Theory of Art and Media Studies, Department of Aesthetics, Eötvös Loránd University, Budapest, Hungary; e-mail: sradnoti@ gmail.com
}

in the painting nor in a second sketch, it is more likely that the theme underwent a subsequent alteration. ${ }^{2}$ Marcel Röthlisberger, the leading expert on Claude Lorrain and the author of the artist's catalogue raisonné, guided by iconographic assumptions that, to me, are far from convincing, identified the figure as the Prophet Ezekiel. ${ }^{3}$ H. Diane Russell, curator of the great exhibition held in Washington and Paris to mark the tercentenary of the artist's death, and author of the accompanying catalogue, took certain formal observations as the starting point for her conjecture that the man on the shore could be the Apostle Paul. ${ }^{4}$ Taking account of these two modern identifications, Margaretha Rossholm Lagerlöf stated quite straightforwardly that the painting represents "a prophet or philosopher on a beach with mighty ruins and a vessel." In the footnote she added, in jest or perhaps in irony, that the figure in the picture could even be Chryses, priest of Apollo, begging for the return of his daughter from Agamemnon, who brusquely chases the priest away, as related at the beginning of the Iliad. ${ }^{5}$ And indeed, 


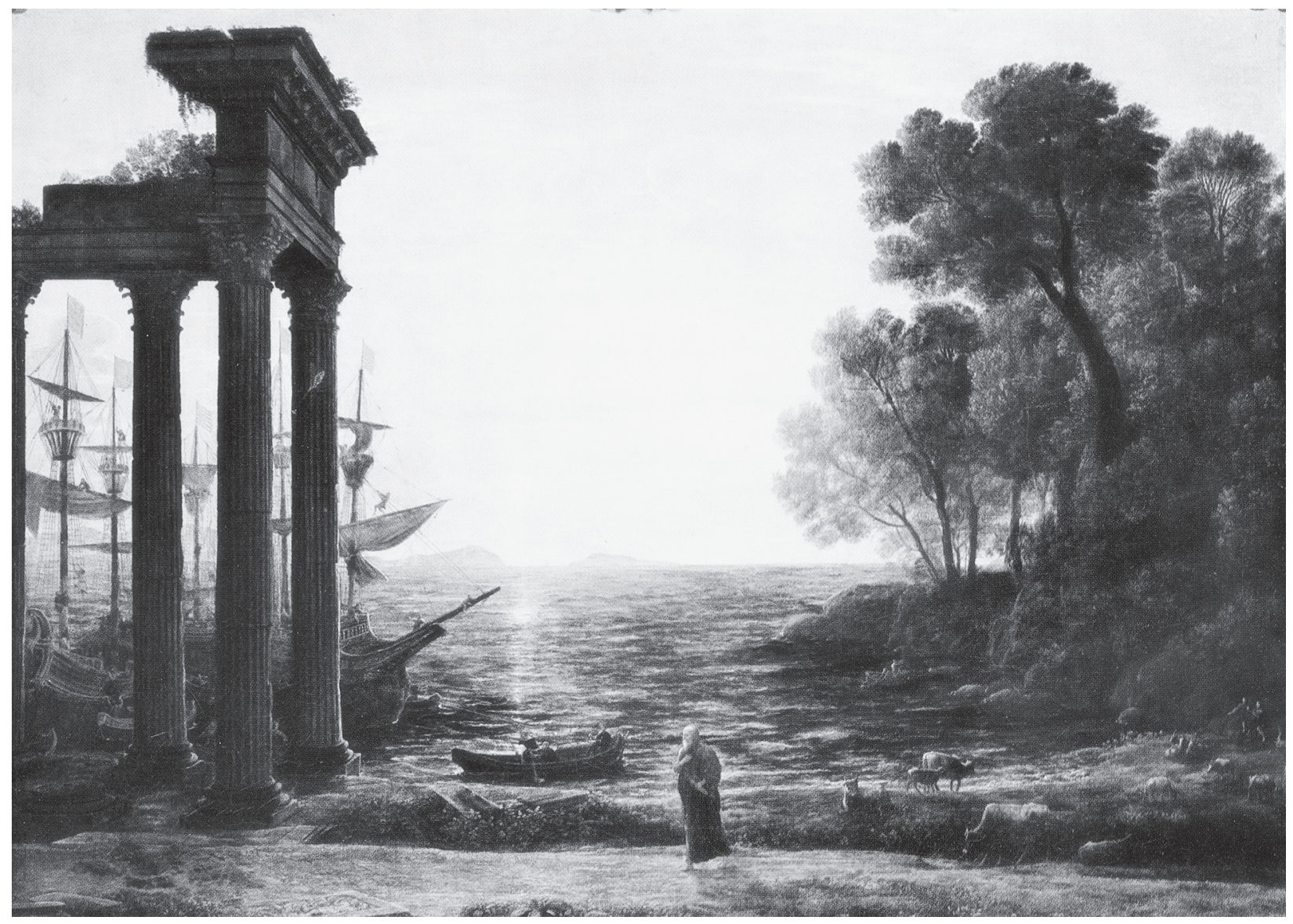

Fig. 1. Claude Lorrain: An Old Man on the Sea Shore, 1667; Duke of Sutherland, Mertoun House

although the idea can never be substantiated, it would be hard to find a better line of literature to describe the scene than, "Silently, he walked the shore of the echoing sea."

The above suggestions broadly delineate the cultural sphere from which the subjects for paintings in the age (and workshop) of Claude Lorrain were taken (or to be more precise, commissioned): the Bible (Old and New Testament) and works of classical literature and mythology. If we elaborate on this with a few specific examples (Ovid's Metamorphoses, Virgil's pastoral poetry and his Aeneid, the Legends of the Saints, Torquato Tasso's Jerusalem Delivered, pastoral scenes predominantly executed in the manner of classical antiquity, genre pieces centred around harbours, peasant dances), then we have before us more or less the entire body of thematic material from the life's work of Claude Lorrain. But why, in my opening sentence, did I describe the situation of not knowing the specific subject of this painting as fortunate?

Claude Lorrain was one of the first painters in the long march of art history to break away from literary (religious, mythological) themes and to veer in the direction of more open interpretations of meaning, or indeed towards indeterminateness. His work had been preceded in the generation before him by the intentional stylisation of the subject matter into a game, a puzzle or a mystery, even perhaps a deliberate absence of theme or one of only incidental significance. Though we may detect an unmistakable indifference towards the subject in many works by Claude, this is not a reflection of the conflict between Northern European description and Southern European narration, as Svetlana Alpers uncovered in her book, ${ }^{7}$ for the young artist, who stemmed from beyond the Alps, was fully conversant with the narrative tradition of Roman (and Venetian and Bolognese) painting. Works by Claude that have positively identifiable themes are scenes of a narrative nature, yet it is no coincidence that the titles that were - or could be - applied to such paintings would have been inconceivable to members of earlier generations dealing with similar topics: Landscape with Acis and Galatea (1657, Dresden), Seaport with Ulysses Returning Chryseis to Her Father (1644, Paris), Landscape with Abraham Expelling Hagar and Ishmael (1668, Munich; Fig. 2). 


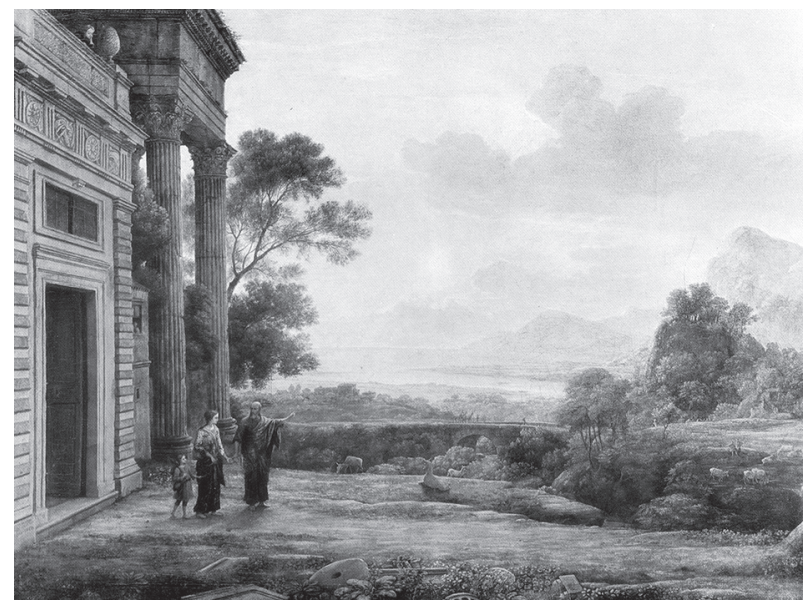

Fig. 2. Claude Lorrain: Landscape with Abraham Expelling Hagar and Ishmael, 1668; Munich, Alte Pinakothek

As told by Ovid, the story of Acis and Galatea is a drama-filled myth that is far from idyllic: Polyphemus the Cyclops espies the lovers locked in an embrace, and in a jealous rage he unleashes boulders from the mountainside, which tumble to the ground and crush Acis, whose blood is subsequently turned into a river. In Claude Lorrain's painting all three characters are present, and the one-eyed giant has already spotted the nymph and the shepherd boy. Nevertheless, when Dostoevsky described what he had seen in Dresden (returning to the memory three times in the 1870s: in Demons, in The Adolescent and in The Dream of a Ridiculous Man), it was not as a horrific episode, but as a golden age:

...blue, caressing waves, islands and rocks, a luxuriant coastline, a magic panorama in the distance, an inviting sunset - words cannot express it. Here European mankind remembered its cradle, here were the first scenes from mythology, its earthly paradise ... Here beautiful people lived! They rose and lay down to sleep happy and innocent; the groves were filled with their merry songs, the great abundance of their untapped forces went into love, into simplehearted joy. The sun poured down its rays upon these islands, and this sea, rejoicing over its beautiful children. A wondrous dream, a lofty delusion! ${ }^{8}$

Abraham banishing his handmaid Hagar and their child Ishmael to the wilderness is a dramatic episode with global repercussions, relating to how two peoples - the Jews and the Arabs - arose in a state of conflict. In Claude's treatment, however, just as Polyphemus reclines almost magnanimously on the mountainside in the painting referred to above, here Abraham seems to be ushering them on their way with grace and courtesy.

The painting of Chryseis is not a landscape. Claude Lorrain's contemporary, Filippo Baldinucci (1624-1697), who wrote a biography of the painter after his death, made clear distinctions between his main genres: pittore di paesi, prospettive e marine, that is, he was a painter of landscapes, buildings and seas. ${ }^{9}$ Scenes of seaports are combinations of seascapes and architectural paintings. This magnificent painting brings the hustle and bustle of a busy port vividly to life, and we can see ships setting sail, coming into harbour and mooring, rowing boats traversing the waters to and fro, cattle being taken ashore, turbaned figures and knights conversing, and a wealth of other activity, while the actual subject of the work (the scene from Book 1 of the Iliad, when Chryses, assisted by Apollo, finally sees the return of his daughter) is represented by a cluster of small and barely identifiable figures in the mid-ground, at the top of the palace steps. If we were not aware of the painting's title, it would be impossible to deduce the theme. We may call this a Mannerist artifice, but relegating the main subject and the main players to the obscurity of the background in this painting does not serve the same essential function as in some of Bruegel's works (see Auden's famous poem, Musée des Beaux Arts, which references, among others, The Fall of Icarus). It seems rather to indicate that the painter was less interested in the topic than he was in capturing the light. "There is none of the real passion associated with love or death in the fragile hesitant people who populate the paintings of Claude." 10

Relatively early in his career, Claude Lorrain earned a reputation as a landscape artist par excellence. He achieved such a level of popularity - paralleled at the time only by Rubens and Van Dyck - that distinguished collectors had to wait years for one of his paintings, while counterfeiting became so widespread that the artist was compelled to document all his works, with drawings of each and every painting he made kept in a register that he called the Liber veritatis. His success continued unabated throughout the whole of the following century, and together with a few of his contemporaries (Salvator Rosa, Nicolas Poussin, Gaspard Dughet, Jakob van Ruisdael, and sometimes David Teniers the Younger and Aelbert Cuyp, although Claude was generally regarded as the primus inter pares), he was responsible for defining how people saw the land around them, in two different senses: firstly, his landscapes were recognised in nature, and 
secondly, they were also recreated in the grounds of (principally English) country houses through the art of landscape gardening. A further contribution to this new way of seeing was made by the invention of a novel device, used especially by painters and connoisseurs of nature, consisting of a darkened, slightly convex mirror, known as a Claude glass; smaller versions could be taken on trips protected in a carrying case, while some larger Claude glasses were mounted on the owner's carriage. When the landscape was observed through one of these mirrors, its colours and composition would be transformed in a way that was reminiscent of a Claude painting. Authors of phenomenally successful illustrated travel journals, such as William Gilpin, would always keep a Claude glass about their person as they roamed the countryside for inspiration, and a drawing by Thomas Gainsborough from around 1750 shows a man (perhaps the artist?) using one.

We cannot ignore the fact that Claude Lorrain's incredible influence came about despite the prevailing ideology of the time in literature, theory and criticism on art. While Claude was still alive, not a single theorist put pen to paper concerning his œeuvre; a parallel may be drawn between this state of affairs and certain twentieth-century ideologists of high culture (such as Adorno and Clement Greenberg), who tended to hold popular and successful artistic registers in disdain. Enthusiasm for Claude reached such giddy heights in the eighteenth century, however, that the academic hierarchy could no longer refrain from issuing a response, although they did so with certain reservations. Claude was either classified as a history painter, or else treated as a standalone exception. Sir Joshua Reynolds, for example, in a discourse he delivered at the Royal Academy in 1778, declared that:

...perfection in an inferior style may be reasonably preferred to mediocrity in the highest walks of art. A landscape of Claude Lorraine [sic!] may be preferred to a history of Luca Jordano [sic!]; but hence appears the necessity of the connoisseur's knowing in what consists the excellence of each class, in order to judge how near it approaches to perfection. ${ }^{11}$

Goethe was a lifelong admirer of Claude's works, and took a keen interest in the entire genre of landscape painting, but as a cultural theorist and an educator he nevertheless toed the line with the classical hierarchy. While this was going on, critics of academic art emblazoned Claude's name on their banners.
In the paintings of Claude Lorrain, members of his own times and - even more so - the century that followed could celebrate not only the embodiment of beauty but also the art of beauty, which was beginning to mark out its autonomy from metaphysical speculation and from the politics of the throne and the altar; instead of the image being treated as a parable, subject to constant reinterpretation in accordance with the concept of the idea, it could now be seen simply as a visualisation of the ideal of the individual. It is even possible to assert, borrowing the views of Hans Belting, that in the history of the image, Claude Lorrain, by liberating himself from the "theme," was among the artists who launched the "Era of Art." Hans Georg Gadamer, though referring primarily to the still life, taking the landscape as a parallel phenomenon, has called the same process the "silencing or speechlessness of the image,"12 and this seems perfectly applicable to the art and personality of Claude Lorrain, who was indeed one of the most taciturn masters of painting in the history of art: ${ }^{13}$ although his life is relatively well documented, there is hardly a single surviving statement of his that refers explicitly to the meaning in his art or provides any explanation of his paintings.

Were I to comply with the communis opinio of the past three hundred years in naming Claude a painter of landscapes, then I would do so without implying the same type of specialisation that defined certain minor (and sometimes even a few of the major) Dutch masters of the same period, who concentrated on a particular genre type or set of recurring themes, or even those foreign artists operating in Rome, who were obliged to carve out their own unique territory if they wanted to stand out. ${ }^{14}$ Claude's career may have begun in such a narrow vein, but it soon expanded its scope. In any event, in Claude's work, the hierarchy of the subject and the scenery was turned on its head. He sought subjects for his works - or later, in recognition of his talent, subjects would be commissioned from him - which allowed the landscape to flourish as the main topic. He focused exclusively on the open air, and even when painting scenes from the life of Jesus, he selected episodes in which the landscape could be afforded at least equal rank. This explains why the Flight into Egypt (following in the footsteps of Annibale Carracci and Domenichino) features so disproportionately in his life's work. The biblical pastoral was characteristic of the way he handled his topics. The primacy of the landscape, resplendent in light and atmosphere, does not in any respect mean that the figures in his paintings are superfluous, as was opined 
on more than one occasion in the age of romanticism. It is indisputable, however, that the all-too-common static, doll-like nature of his human depictions did not escape the notice of his contemporaries, who often regarded his figures as somewhat maladroit, to the extent that rumours abounded of how he engaged others to paint the people in his works. (The generally accepted view among art historians today is that, even if true, he probably did this only at the very beginning of his career.)

The lack of emotion in his figures, which has also been described as calmness, ${ }^{15}$ deserves, in my opinion, to be given an alternative interpretation. A few of the examples I have presented demonstrate that this dispassionateness is frequently at odds with the narrative in the painting, and further examples could be added at will. It is the landscape that takes precedent over the events themselves; Claude, unlike his great contemporary Poussin, did not subjugate nature to expressing human passions, or rather, the suppression of such passions. The contrast can be seen in Poussin's Landscape with Polyphemus (1649, Saint Petersburg), in which the giant is seated on a mountain peak, playing his melody of love on his flute. The sun-drenched valley is fertile and idyllic, but the ominous forms of the cliffs and the gathering clouds foretell the calamity that is about to unfold. ${ }^{16}$

Not so in Claude's works, where nature is never anything but beautiful and indifferent. It provides a backdrop to human action without entering into mutual interaction. To mention perhaps the most obvious piece of evidence for this, there is, in Claude's entire ouvre, hardly a storm in sight, the land is forever calm and cheerful, never wintry, and his trees are never bare. All that changes is the time of day: dawn, noon and dusk, with the sun rising, reaching its zenith and setting. The horrifying drama in Poussin's Landscape during a Thunderstorm with Pyramus and Thisbe (1651, Frankfurt) takes place beneath a frighteningly tempestuous sky: riders, herders and their flocks flee in terror from the fearsome lion and the forbidding flashes of lightning, while the trees are bent by the force of the wind, and yet, inexplicably, in the mid-ground of the painting, the surface of the lake is smooth as a mirror - what could be the reason for this perfect tranquillity? Could it be some anecdotal oversight, like the mysterious third foot that apparently belongs to one of the men carrying the dishes in the foreground of Bruegel's Peasant Wedding? I do not think so. At this point I would like to share the exquisite interpretation written by Louis Marin:
Or does the lake, as a figure of the painting, play in the painting a character other than those who cooperate with destiny or resist it, a different character, one that is no longer a character belonging to the painting but is rather the great eye of the viewer, of the sage who has been brought back to himself by the representation of the unrepresentability of the tempest and the human passions? This sage-lake would figure a reduced gaze, returned to its eye, after all the trajectories and all the readings of the places, spaces, and figures of the painting; it would figure a gaze that is now serene, since it is aligned with itself in the present presence of the instrument that has been the instrument of this return, the painting, that of Pyramus and Thisbe, that of a tale of two unhappy lovers reunited only by the death... ${ }^{17}$

This state of calm, which Poussin arrived at by passing through tumultuous drama, was second nature to Claude Lorrain. It is for this reason - namely, that it would be impossible to imagine two more contrasting characters - that I derive a certain comfort from the unverified biographical account describing how the two foreign painters in Rome, the contemplative pictor doctus and the naive pictor faber, would meet up as elderly neighbours to chat over a few cups of wine.

Unlike Poussin, who is frequently labelled cold and didactic, meticulous as an engineer, and well versed in classical philology and archaeology, Claude, with his tender gentleness, is oriented in completely the opposite direction; this essentially means that while Poussin conducts a dialogue with nature based on heroic human deeds, stoic, republican principles and geometric rationality, Claude observes human endeavours from the perspective of nature, which endures unalteringly even through its cyclical changes. With Poussin - so says Anthony Blunt - substance is the aim and light is the means, whereas with Claude the reverse is true. Poussin's trees are solidly constructed, whilst Claude's are without structure, pure masses of vibrant light.

With Claude the leaves will move and the light will change in the next second; with Poussin the leaves have the fixity of stone, and the light the steadiness of noon-day. Claude gives his buildings something of the insubstantial quality of trees; Poussin makes his trees as static and solid as temples. Here again Poussin, in the true classical tradition, seeks the permanent, unchanging 
aspects even in changing nature; Claude records the passing effect, seized on the moment. ${ }^{18}$

Wherever one looks, one can read that Claude Lorrain is the unequalled master of light and atmosphere. Though everything may change, what remains is the calm state of being that ensues from the eternal constancy of nature. It is difficult to apprehend where the counterpoint to this splendid permanence, divided only by the rhythm of nature, may be found. We can easily see what nature, in all its captivating beauty, has to say for itself, but we are less certain when it comes to humanity. The answer we seek cannot yet be the painterly vision and action that will one day elevate Cézanne's unpopulated landscapes to the ranks of the very greatest, for the conventions of painting do not yet permit us to step away from the fiction of imitating nature, not even if the nature on show is clearly an idealisation and no reflection of reality. Nor do I believe there is any truth in the proposition, as Dostoevsky and so many others have claimed, that Claude's paintings exhibit a longing to return to some kind of halcyon days of nature. These images are too reserved for that, and they fail to invite us to step inside them. Claude's works may be typified not by nostalgia, but in fact by an elegiac atmosphere, and in the supreme exemplars of his œuvre we may espy the long-sought answer, expressed as follows by Margaretha Rossholm Lagerlö in her most outstanding book:

The human state in Claude's landscapes bespeaks an attitude of bitter-sweet acceptance: this wonderful earth is all ours, we can dwell here, but only for a while, without seeing clearly, without making a mark; neither our rise nor our fall has any effect on nature's beauty. ${ }^{19}$

The figures in almost all of Claude's landscapes are characterised by an activity of some kind, albeit a subdued activity. There are only two of his paintings in which the central characters share the same contemplative approach by which the artist is defined. One is his Landscape with Psyche in Front of the Palace of Amor (1664, London; Fig. 3), while the other was painted three years later in 1667 , and forms the main subject of this essay; here I have given it the title An Old Man on the Sea Shore. It is the property of the 7th Duke of Sutherland, and it hangs in Mertoun House ${ }^{20}$ (Fig. 1).

The painting in Mertoun House measures $114.5 \times 159 \mathrm{~cm}$. The spectacle is framed on the left

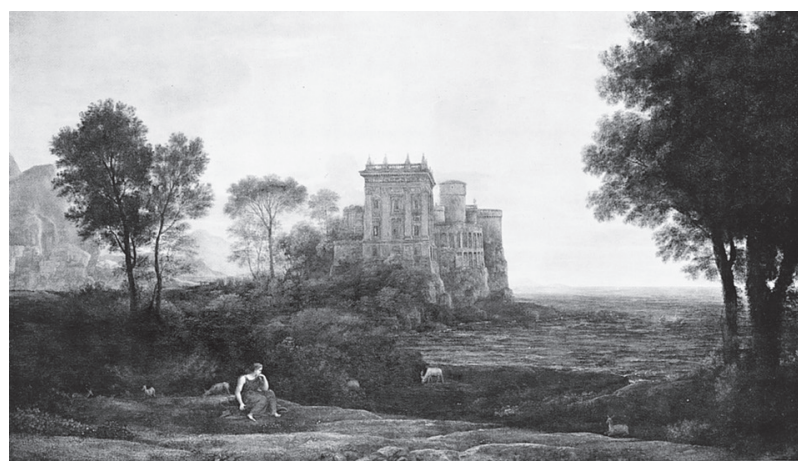

Fig. 3. Claude Lorrain: Landscape with Psyche in Front of the Palace of Amor, 1664; London, National Gallery

by an open portico with four full Corinthian columns, although its tripartite entablature is heavily damaged and overgrown with ivy. On the right is a clump of eight or nine trees marking the edge of small wood that encroaches upon a promontory that juts into the ocean, forming a natural cove. Fringing the low horizon, two fifths of the way up the canvas (as is customary in Claude's works ${ }^{21}$ ) and reaching from the left edge approximately halfway across the painting, is a chain of mountains. Visible through the columns of the portico is a high-decked, round-bottomed ship with five (!) masts. (This work was preceded by fourteen seaport scenes, featuring many ships, which he painted between 1636 and 1648.22) The rigging and the crow's nests are humming with activity, and the vessel seems to be getting ready to weigh anchor. Some cows are grazing on the strip of land in front of the trees, and close to the edge of the picture two shepherds stand tending their flock, while further away, in the shadow beneath the trees, two men can be made out in a small boat by the shore. All the above constitutes, in a broad sense, the frame of the spectacle, and vertically occupies a third of the painting on both left and right.

In the middle third of the painting we can see the sea, face-on, as was the painter's custom (Fig. 4). The sun is setting directly opposite us, tinting the sky with an orange hue and turning the water and the land into shades of deep blue and dark brown. The vertical of the solar bridge reflected in the ocean is to the left of centre, in accordance with the golden ratio (as is the line of the horizon). The strip of light almost intersects the bowsprit of the sailing ship and reaches as far as the rowing boat in the foreground, which is about to land or could perhaps have just pushed off into the water. There are two men at the oars and one passenger. Up on the shore beside them, a large chunk of fallen stone from the entablature lies flat on the ground. 


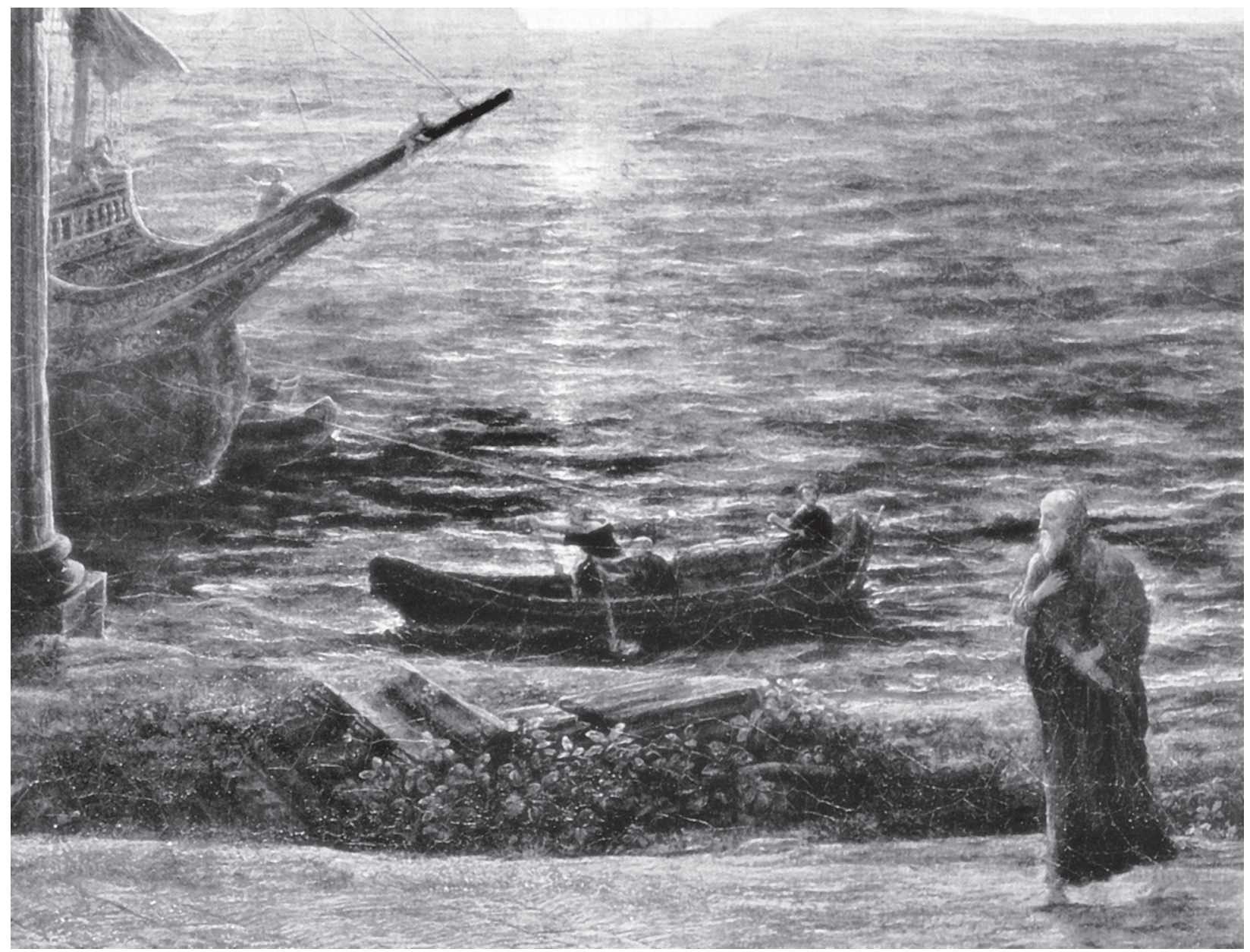

Fig. 4. Claude Lorrain: An Old Man on the Sea Shore, detail

Walking along a path that runs parallel with the edge of the sea, bathed in the glow of the setting sun, an old man is moving away from the trees and towards the ruined building. He is almost exactly halfway across the painting, and although he is by far the largest figure in sight, he takes up no more than about fifteen per cent of the height of the work.

Reducing the size of the figures in landscapes was one of the features that distinguished the genre from the compositions of history paintings. When the land was transformed from background into main subject, then - simply put - the figures could not be permitted to cover it up too much. This posed a problem in Southern European landscape painting, which insisted on preserving the narrative function, because the diminution of the figures also deprived them of their significance. This, and not a lack of dexterity, was the reason why Claude's figures often appeared puppet-like, for his works conveyed the message that any human activity is unavoidably dwarfed by nature. This prompted these apt words from Roger Fry:
Claude is the most ardent worshipper that ever was of the genius loci. Of his landscapes one always feels that "some god is in this place." Never, it is true, one of the greater gods: no mysterious and fearful Pan, no soul-stirring Bacchus or all-embracing Demeter; scarcely, though he tried more than once deliberately to invoke them, Apollo and the Muses, but some mild local deity, the inhabitant of a rustic shrine whose presence only heightens the glamour of the scene. ${ }^{23}$

It follows on from this that perfect harmony between the work and its theme can most satisfyingly be discerned in Arcadian pastoral scenes and in mythological episodes where humans are torn away from nature only to be transformed once again back into part of nature itself. Thus, Claude Lorrain found some of the most ideal source material for his paintings in Ovid's Metamorphoses, such as the afore-mentioned story of Acis and Galatea, as well as the theme of his magnificent late masterpiece, Landscape with Perseus and the 
Origin of Coral (1673, Coke Collection, Holkham Hall, Norfolk).

Once more I have to say that exceptions can be found: the figure in the London Psyche (often referred to since the end of the eighteenth century as The Enchanted Castle, this work famously enchanted the poet John Keats), deeply meditating on the majesty of nature, is herself majestic despite her tiny stature; and then there is the no less majestic old man in the Mertoun House painting. It is worth comparing the latter with the rest of the elderly male figures in other major works by Claude Lorrain (such as Laban, whom he painted on three occasions [one example being Landscape with Jacob, Laban and His Daughters, 1654, Petworth House; Fig. 5], Anchises [Landscape with Aeneas at Delos, 1672, London; Fig. 2] or Abraham Banishing Hagar and Ishmael [Munich, dated 1668, close to the date of the painting in Mertoun House]): clearly, the old man on the sea shore stands apart from them all, both in quality and in significance. To elaborate in general terms, whereas Laban, Anchises and Abraham share no connection with the landscape unfolding behind them, the pure contemplation of nature in which the Mertoun House figure is immersed, and his acceptance that he is at the mercy of nature, mean that his smallness and his fragility are perfectly compatible with his dignity.

If we divide the painting that forms the subject of this essay vertically into three approximately equalsized sections, then - proceeding in the same direction as the main figure is walking - the first third from the right depicts, in the foreground, the pastoral scene that Claude revisited so many times in his career, whilst from the mid-ground almost to the top of the picture there is a dynamic patch of dense foliage, another "hallmark" of Claude Lorrain, familiar from so many of the master's paintings, and many more by his followers and imitators. Here, then, we have an image of untouched earthly nature, or at least it has been disturbed only to the slightest extent by the grazing of animals.

By contrast, in the left-hand third Claude gives us a portrayal of the human world, and what is more, he does so via the extraordinarily inventive device of showing us the human world of the present - where sailors are busily equipping their vessel for the next journey - through the "bars" (columns) of the human world of the past - in which a man-made structure has not just fallen into disrepair, but is even being reconquered by the natural world. Contrary to what we might think, Claude, in his paintings of archi-

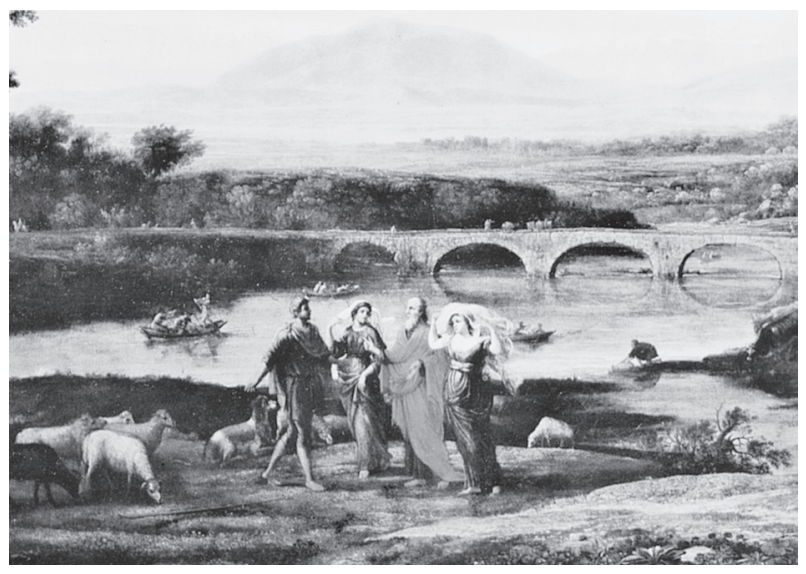

Fig. 5. Claude Lorrain: Landscape with Jacob, Laban and His Daughters, 1654, detail; Petworth House

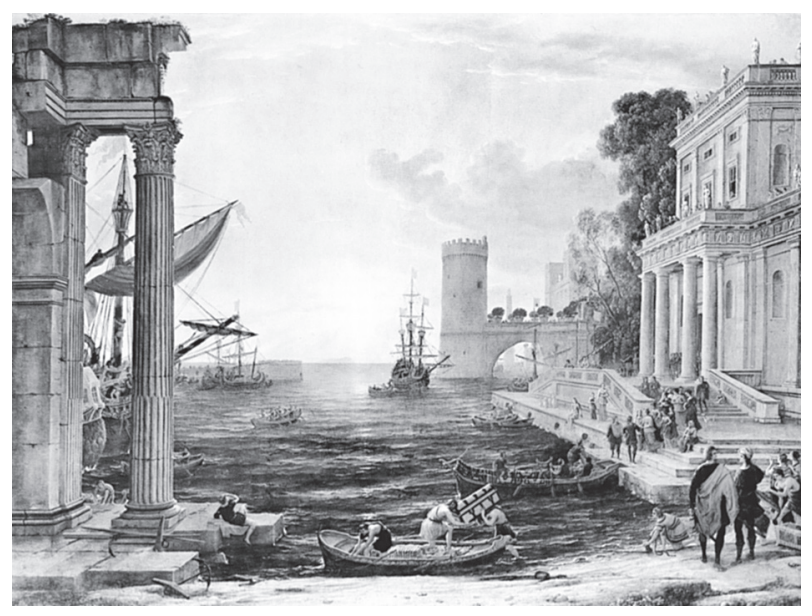

Fig. 6. Claude Lorrain: Seaport with the Embarkation of the Queen of Sheba, 1648; London, National Gallery

tecture, actually preferred to restore the buildings of antiquity to their erstwhile glory, but he was also bound to convention in sometimes including ruins in his landscapes. He began to use the type with four columns (or pilasters) in the 1660s. ${ }^{24}$ For his previous depiction of ruins on a similar scale (also on the left of the painting, but only with two columns), we have to go as far back as 1648, to his sumptuous Seaport with the Embarkation of the Queen of Sheba, now in London (Fig. 6). Here too, a great sailing ship can be seen through the gap between the columns, proving that this method of arranging motifs was already part of the master's toolbox many years before. In the Mertoun House painting, however, the idea takes on a more profound meaning, as the decrepit ruin and the lively vessel enter into dialogue with each other. The former seems to be saying to the latter that it too was once created and inhabited by living hands, while also intimating that the ship will one day surely meet a similar destiny. 
The act of framing his pictures by placing a portico on the left and a clump of trees on the right had also long belonged to Claude's repertoire. ${ }^{25}$ I have called the two outer thirds of this picture the frame in the more general sense of the word - because the repoussoir technique of including tall objects along the sides that occupy almost the entire vertical space - in this case the open columns and the forest - generates depth in the central third of the painting, which - apart from the narrow strip of coast - is an image of the sea and the sky, centred on the old man and the rowing boat. The magnitude of Claude's art inheres in the fact that this framing - the two vertical thirds of the picture - has no detrimental effect on the optical unity that pervades the entire canvas. This unity is often explained simply in terms of the unifying effect of the light, with Claude treated as a Turner or a preimpressionist who had somehow stumbled into the wrong century. Max Imdahl, however, reminded us all that Claude was a classicist, and he attributed the pictorial unity to the artist's use of geometry and "tectonic pictorial architecture" - the proportionality apparent in the intermediate spaces, the formal independence of the surfaces of the empty spaces (i.e. they are not simply the negatives of the silhouettes of the trees, for instance) and the firm delineation of the contours. ${ }^{26}$

The central third of our picture forms a connection between the setting sun and the old man, whose bald pate, face, beard and right arm are drenched in warm sunlight. The flipside of this connection, however, is that he has lost his links with the human world, both with that of the pastoral scene, and with the one aboard ship. This comes naturally with old age. Yet the old man has not left the human world. The scroll in his hand bears a text that was written by people for other people. His solitude does not equate with a fathomless, bewildering void, as in the famous later painting by Caspar David Friedrich; it means only that he is deep in his own thoughts, blocking out the active world, isolating himself from all its pulsations, and yielding to the peace and quiet of nature. His dignity is augmented by the fact that, despite his relatively small size, he is still larger than any of the other figures in view. Sometimes in Claude's works, and almost always in seaport scenes, the staffage figures appear larger than the central characters, but not in this painting.

Despite the fact that I have spent years looking at the few reproductions that are of decent enough quality, and even though I have seen the original up close, it is only now, having enlarged the photographs I took there to the maximum extent possible, that I realise that while the old man is locked inside his own thoughts, his isolation is not entirely mutual. The passenger in the rowing boat, it now becomes apparent, is looking straight at him. It is in this single gesture that the lost narrative has been preserved. Whether this passenger is actually "one named Julius, a centurion of Augustus' band" - Acts 27:1 - (if it is him, why is the old man identified as Paul the Apostle not his prisoner?) or someone else, we can never know, and perhaps it is not important ever to find out. The essence of the painting is not within the subject that once surely existed, but in the old man's relationship with nature, to which he must soon surrender his bones. A man is walking in the face of his natural destiny, which is written in the land that surrounds him.

\section{NOTES}

${ }^{1}$ According to tradition, beside the Bay of Phalerum, close to Athens, "Demosthenes used to practise declaiming on the beach, to learn to pitch his voice so as to overcome an uproar." (CiCERO: De finibus bonorum et malorum, V. 2.) In 1776 Richard Earlom (1743-1822) made a mezzotint etching after the work by Claude, which was published by John BOYDELL (1720-1804) under the title Demosthenes on the Sea Shore (Liber Veritatis, 171). The painting was discussed with the same title by John SMith in his work, A Catalogue Raisonné of the Most Eminent Dutch, Flemish and French Painters Vol. VIII. Containing the Life and Works of Nicholas Poussin, Claude Lorrain and Jean Baptist Greuze, London: Smith and Son, 137, New Bond Street, 1837. 287.f., no. 171. (https:// babel.hathitrust.org/cgi/pt?id=nyp.33433022917367;view= lup;seq=9)

In the letters he wrote about English art collections, which were widely read in their day, the Berliner museum director Gustav Friedrich Waagen (1794-1868), in the German edition of 1837, described an old man walking along the shore, but when the English translation was published in 1854, the figure was now named as Demosthenes. cf. WAAGEN, Dr. G. F.: Kunstwerke und Künstler in England, Berlin: Nicolaische Buchhandlung, 1837. Vol I, 332; WAAGEN, Dr.: Treasures of Art in Great Britain: Being an Account of the Chief Collections of Paintings, Drawings, Sculptures, Illuminated Mss., Ec. Ec., London: John Murray, 1854. Vol. II, 38. The monograph and catalogue of Claude written by Lady Dilke (1840-1904) is interesting in that the painting - due to a lack of concern for iconographical matters - is accorded two different names: in the chronological list, the title is given as Marine avec Démosthènes, while in the catalogue, where the works are listed according to their location, the same work is called Grande marine avec architecture. cf. PAtTison, Mme Marc: Claude Lorrain, sa vie et ses œeuvres, Paris: Librairie de 
l'art, 1884. 191, 231. Further mentions: op. cit. 94, 110, 221. The literature from later in the nineteenth century continues to identify the subject of the painting as Demosthenes. cf. e.g. Dullea, Owen John: Claude Gellée le Lorrain, New York: Scribner and Welford, 1887. 116, 124; GrahAME, George: Claude Lorrain, Painter E Etcher, London: Shelley and Co., New York, Macmillan and Co., 1895. 50.f.; BERZEVICZY, Albert: A tájképfestés a XVII. században [Landscape Painting in the 17th Century], A Magyar Tudományos Akadémia Kiadása, 1910. 87. The painting was more widely known in the nineteenth century than it is today, despite the fact that it has never been on show in any public collection, neither then nor since, and both Waagen and Dilke regarded it as one of Claude's chefs d'œuvre.

${ }^{2}$ cf. Röthlisberger, Marcel \& CeCchi, Doretta: L'opera completa di Claude Lorrain, Milano: Rizzoli, 1975. 119.

${ }^{3}$ cf. Rothlisberger, Marcel: Claude Lorrain. The Paintings, New Haven: Yale University Press, 1961. Vol. I, 403. His three arguments are: 1 . the scroll in the man's hand indicates that he is a prophet; 2 . a small relief in the bottom left quarter of the painting, whose details are now difficult to determine, is alleged to depict two figures, one kneeling and one standing, in supposed reference to the reanimation of the dead witnessed by Ezekiel in the valley of dry bones (Ez. 37); 3. the ruined temple and the ship visible in the left of the painting - the direction in which the old man is looking - represent the destruction (and erstwhile glory) of the Phoenician coastal city of Tyre, which was laid to waste by the Lord, as foretold and later lamented by the prophet (Ez. 26, 27). According to this interpretation, the picture therefore shows Ezekiel mourning the destruction of Tyre.

${ }^{4}$ cf. Russell, H. Diane: Claude Lorrain 1600-1682, New York: George Braziller, in association with National Gallery of Art, Washington, 1982 (catalogue), Fig. 88. A small painting of 1654, i.e. thirteen years before this one (Birmingham, City Museum and Art Gallery), has a remarkably similar composition. The theme of the Birmingham painting is beyond doubt: it shows the Embarkation of Saint Paul as he sails for Rome, as described in Acts 27: 1-2. If, despite the obvious difficulty (the striking age difference between the two versions of Paul), this identification were correct, then the ruined temple would symbolise the Old Testament and the ship would stand for the ecclesia; the scene that is allegedly spelt out on the fallen stone would also serve a similar function, although according to the new interpretation it would now be one figure standing on top of the other. The artist tended to paint most of his pictures (by some estimates two thirds of his œuvre) in pairs, and the work in question also has its pendant (exceptionally housed in the same place), titled Landscape with Moses and the Burning Bush (Mertoun House, property of the Duke of Sutherland). Although it would be far from accurate to state that Claude's pairs of pendant pieces were generally connected by theme (for the relationship is often characterised solely by the atmospheric contrast of time of day [dawn and dusk] or type of scenery [landscape and seascape] and by the harmony between the lines of the horizon), the argument goes that Moses was frequently mentioned by Paul, and the Neo-Platonists of Florence were emphatic in their insistence that they were of mutual relevance. The picture draws a parallel between the young Moses and the elderly Paul, and this opens the way for iconographical identification of the contrasts between the
Old and the New Testaments and their mutual references. cf. Russell, Diane: Claude's Psyche Pendants: London and Cologne, in Claude Lorrain 1600-1682: A Symposium, ed. AsKEW, Pamela, Washington: National Gallery of Art, 1984. 71.

${ }^{5}$ Rossholm Lagerlöf, Margaretha: Ideal Landscape. Annibale Carracci, Nicolas Poussin and Claude Lorrain, New Haven -London: Yale University Press, 1990. 81, 237 [note 78].

${ }^{6}$ Homer: The Iliad I. 34.

${ }^{7}$ cf. Alpers, Svetlana: The Art of Describing. Dutch Art in the Seventeenth Century, Chicago: University of Chicago Press, 1984

${ }^{8}$ Dostoevsky, Fyodor: Demons, translated by PeVear, Richard - VolokHonsky, Larissa (1994, Alfred A. Knopf, Inc.), 703, "At Tikhon's." Originally intended by Dostoevsky for Chapter 9 of Part Two of the novel, the chapter from which Stavrogin's dream comes was suppressed by his editor and never restored during the author's lifetime. Three years after Demons was first published Dostoevsky used these words almost verbatim for Versilov's dream in The Adolescent.

${ }^{9}$ The Life of Claude by Baldinucci, in ROTHLisBERGER: Claude Lorrain. The Paintings, loc. cit. Vol. I, 53.

${ }^{10}$ Rossholm LagerlöF: Ideal Landscape, loc. cit. 110.

${ }^{11}$ Discourses Delivered at the Royal Academy [1780], in The Literary Works of Sir Joshua Reynolds, London: Henry G. Bohn, 1852. Vol. 1, Discourse VII, 422. For Claude see also Discourse IV, loc. cit. 359.f. The English particularly admired, copied and collected works by Claude Lorrain, as a result of which approximately one third of his known ouvre can be found in Britain today. When Horace Walpole published his description of his family's art collection, he called Claude "the Raphael of Landscape-painting." cf. Aedes Walpolianae, or, A description of the collection of pictures at Houghton-Hall in Norfolk, the seat of the Right Honourable Sir Robert Walpole, Earl of Orford ..., London, 1752. XXXI.

${ }^{12}$ I refer to the secondary title of Hans BeLTING's masterly work Likeness and Presence (Bild und Kult): A History of the Image before the Era of Art. Gadamer's lecture of 1965: Vom Verstummen des Bildes, in GADAMER: Gesammelte Werke. Bd. 8. Ästhetik und Poetik. 1. Kunst als Aussage, Tübingen: Mohr 1993. 315-322.

${ }^{13}$ Michael Kitson called him the great introvert of art history, as opposed to the great extrovert, Rubens. cf. KITSON, Michael: The Art of Claude Lorrain [1969], in KiTSON: The Seeing Eye. Critical Writings on Art - Renaissance to Romanticism, London: Mnemosyne Art History Press, 2008. 82.

${ }^{14}$ In Theodor Hetzer's view, Claude does not deserve a place among the greatest masters of his age, who were Rubens, Rembrandt and Velázquez. Even Poussin had a greater range and a sharper intellect. However, Claude cannot be simply classified among the landscape specialists either, of whom there were many practitioners in the seventeenth century, especially in the Netherlands. Claude was one of the artists who helped to shape the grandeur of the grand siècle. cf. Hetzer, Theodor: Claude Lorrain, Frankfurt/M.: Vittorio Klostermann, 1947 [written in September 1944]. Landscape painting had indeed been regarded as the special domain of the Low Countries since the middle of the sixteenth century.

${ }^{15}$ Claude Lorrain was the "master of the 'actions of calm'." MÉrot, Alain: Du paysage en peinture dans l'Occident moderne, Paris: Gallimard, 2009. 146. 
${ }^{16}$ Kurt Badt surprisingly dissents from this view, for he sees no dramatic tension of any kind in the painting. cf. BaDt, Kurt: Die Kunst des Nicolas Poussin, Köln: DuMont, 1969. 606.f.

${ }^{17}$ MARIN, Louis: Description of a Painting and the Sublime in Painting: Concerning a Poussin Landscape and Its Subject, in Marin: Sublime Poussin, Stanford (Cal.): Stanford University Press, 1999. 102. Translated by Porter, Catherine.

${ }^{18}$ Blunt, Anthony: The Heroic and the Ideal Landscape in the Work of Nicolas Poussin, Journal of the Warburg and Courtauld Institutes 7. 1944. 164.

${ }^{19}$ Rossholm LagerlöF, op. cit. 155.

${ }^{20}$ Here I would like to take the opportunity to extend words of heartfelt gratitude to my friend, Judit Geskó, for introducing me to Michael Clarke, (now retired) director of the Scottish National Gallery in Edinburgh; to Michael Clarke, for organising my visit to Mertoun House and for accompanying me there; and to the Duke and Duchess of Sutherland, for generously welcoming me into their home and guiding me around their collection of paintings.

${ }^{21}$ cf. Damisch, Hubert: Claude: A Problem in Perspective, in Claude Lorrain 1600-1682, op. cit. 29-44.
22 cf. CoRdingly, David: Claude Lorrain and the Southern Seaport Tradition, Apollo: The International Magazine of Arts 103. 1976. No. 170, 208-213.

${ }^{23}$ FRY, Roger: The Drawings of Claude, Special Number of the Shilling Burlington and Fine Art Chronicle, August 15, 1907. 443. This is echoed by Anthony Blunt: not the great gods, but the small ones. Art and Architecture in France, 15001700, London: Penguin Books, 1953. 198. It is also possible that Fry's observation could be applicable to landscape painting in general. After all, every landscape is a detail, an excerpt taken from the whole of nature, although as a metaphor for infinite finity, it cannot help but be local - with local gods even if the landscape is not realistic but idealised.

${ }^{24} \mathrm{cf}$. Kennedy, I. G.: Claude and Architecture, Journal of the Warburg and Courtauld Institutes 35. 1972. 261.

25 See his beautiful Pastoral Landscape of 1638 (Parham House, West Sussex). An excellent reproduction can be found in Langdon, Helen: Claude Lorrain, Oxford: Phaidon, 1989. plate 38 .

${ }^{26}$ cf. IMDAHL, Max: Baumstellung und Raumwirkung. $\mathrm{Zu}$ verwandten Landschaftsbildern von Domenichino, Claude Lorrain und Jan Frans van Bloemen, in Gesammelte Schriften 2. Zur Kunst der Tradition, Frankfurt/M.: Suhrkamp, 1996. 321. 